\title{
Pyramicocephalus phocarum \\ (Cestoda: Diphyllobothriidea): the ultrastructure of the tegument, glands, and sensory organs
}

\author{
A.R. Mustafina, N.M. Biserova \\ Lomonosov Moscow State University, 1-12 Leninskie Gory, 119234 Moscow, Russia. E-mail: \\ nbiserova@yandex.ru
}

ABSTRACT: The ultrastructure of the tegument, glands and sensory organs of Pyramicocephalus phocarum (Cestoda: Diphyllobothriidea) have been studied. Three types of the microthriches are found, which have a specific distribution on the scolex and body. A welldeveloped basal lamina contained radial anchoring fibrils; they are associated with the microfibrills of the lamina reticularis and form regular cross-links. In the tegument, we have found six types of sensory organs and also terminal pores of the frontal glands. It has been shown that sensory endings and secretory pores are co-localized in the bothria tegument: 30 pores and 50 sensory endings were found in one section. Frontal glands are located in the parenchyma of the scolex and body; glands are well-developed and have intensive eccrine secretion. Comparative ultrastructural analysis of four diphyllobothriidean species shows similarity in the ultrastructure of microtriches and frontal glands in the plerocercoids of $P$. phocarum and Diphyllobothrium latum.

How to cite this article: Mustafina A.R., Biserova N.M. 2017. Pyramicocephalus phocarum (Cestoda: Diphyllobothriidea): the ultrastructure of the tegument, glands, and sensory organs // Invert. Zool. Vol.14. No.2. P.154-161. doi: 10.15298/invertzool.14.2.09

KEY WORDS: tapeworms, ultrastructure, microthriches, basal matrix, eccrine secretion, receptors.

\section{Ультраструктура тегумента, фронтальных желез и сенсорных органов Pyramicocephalus phocarum (Cestoda: Diphyllobothriidea)}

\author{
А.Р. Мустафина, Н.М. Бисерова
}

МГУ им. М.В. Ломоносова, Ленинские горы, д.1, стр. 12, Москва, 119234 Россия. E-таil: nbiserova@yandex.ru

РЕЗЮМЕ: Ультраструктура тегумента, фронтальных желез и сенсорных органов была изучена у плероцеркоида Pyramicocephalus phocarum (Cestoda: Diphyllobothriidea), паразита морских млекопитающих и человека, извлеченного из печени беломорской трески. В тегументе выделено три типа микротрихий, имеющих фиксаторную и трофическую специализацию. Распределение микротрихий на сколексе и теле не равномерно: 1-й тип, крупные фиксаторные миротрихии с закругленным кончиком, обнаружен только на ботриях; 2-й тип, тонкие конические фиксаторные микротрихии - на теле; 3-й тип, трофические микротрихии расположены на сколек- 
се и теле плероцеркоида. Фронтальные железы заполняют центральную и кортикальную часть паренхимы сколекса и продолжаются в тело. Железистый комплекс образует многоядерный синцитий, периферические отделы в виде тонких протоков направленных в тегумент, укреплены микротрубочками. Терминальные отделы желез образуют поры в тегументе, окруженные системой специализированных контактов, через которые происходит выброс секрета. На одном срезе ботрии обнаружено 30 секреторных пор и 50 сенсорных ресничных и безресничных нервных окончаний, колаколизованных с протоками желез. Всего в тегументе P. phocarum выделено 6 типов сенсорных органов. По степени развития фронтальных желез, $P$. phocarum близок к плероцеркоиду Diphyllobothrium latum; сенсорные органы у всех изученных дифиллоботриид сходны по ультратонкому строению окончаний.

Как цитировать эту статью: Mustafina A.R., Biserova N.M. 2017. Pyramicocephalus phocarum (Cestoda: Diphyllobothriidea): the ultrastructure of the tegument, glands, and sensory organs // Invert. Zool. Vol.14. No.2. P.154-161. doi: 10.15298/invertzool.14.2.09

КЛЮЧЕВЫЕ СЛОВА: ленточные черви, ультраструктура, микротрихии, базальный матрикс, секреция, рецепторы.

\section{Introduction}

Tapeworms of the order Diphyllobothriidea are widely distributed all around the world. Some are agents of human diphyllobothriasis, one of the most important fishborne zoonosis caused by a cestode parasite. Our knowledge about the ultrastructure and functional morphology of the plerocercoids, which are the infectious stage of mammalians and humans, is extremely important. Pyramicocephalus phocarum (Fabricius, 1780) belongs to the order Diphyllobothriidea (Kuchta et al., 2008). Adult worms are parasites of seals (Delamure, 1955). Cases of human infection have been described (Rausch et al., 1967). Plerocercoids of $P$. phocarum are parasites of Gadus morhua (Linnaeus, 1758) and others commercial species. Prior to this study, only the biology and gross anatomy of $P$. phocarum have been studied (Delyamure, 1955; Raush et al., 2010). The aim of this study is to describe fine structure of the tegu- ment, glands and sensory organs of the $P$. phocarum plerocercoid, and to compare with other studied representatives of order Diphyllobothriidea.

\section{Material and methods}

Plerocercoids of $P$. phocarum were obtained from the body cavity of Gadus morhua (White Sea, the WSBS MSU, Russia), fixed in $2.5 \%$ glutaraldehyde and post-fixed in $1 \% \mathrm{OsO}_{4}$ in PBS, dehydrated and embedded in Araldite resin at $60^{\circ} \mathrm{C}$. Semi thin and ultrathin sections were stained with methylene blue or with $4 \%$ uranyle acetate and $0.4 \%$ lead citrate and examined under a Jeol JEM-1011 (TEM). For scanning electron microscopy, specimens were fixed and dehydrated as noted above and then criticalpoint-dried, coated with gold and examined under a scanning electron microscope JSM35S JEOL (Biserova, 2013).

\footnotetext{
Abbreviations: a — apical part of the scolex; af — anchoring filaments; b — base; bt — bothria; c — cap; $\mathrm{p}$ - baseplate, $\mathrm{s}-$ scolex. Scale bar: A $-1000 \mu \mathrm{m} ; \mathrm{B}-300 \mu \mathrm{m} ; \mathrm{C}-1 \mu \mathrm{m} ; \mathrm{D}-1 \mu \mathrm{m} ; \mathrm{E}-2 \mu \mathrm{m} ; \mathrm{F}-1 \mu \mathrm{m} ; \mathrm{G}-0.5 \mu \mathrm{m} ; \mathrm{H}-$ $0.5 \mu \mathrm{m}$.

Рис. 1. Pyramicocephalus phocarum: ультраструктура тегумента. А, В - сколекс плероцеркоида; Смикротрихии 1-го типа; D - микротрихии 2-го типа; E - сагиттальный срез микротрихий 1-го и 3го типов в ботрии; F — микротрихии 2-го типа; $\mathrm{G}$ - микротрихии 1-го типа, фронтальный срез; Н - -ультраструктура базальной пластинки с заякоривающими филаментами.

Сокращения: a - апекс; af - заякоривающие филаменты; b - базальная часть микротрихии; bt - ботриальная скадка; с - апикальная часть микротрихии; $\mathrm{p}$ - базальная пластинка микротрихии; s - сколекс. Масштаб: А $1000 \mu \mathrm{m} ; \mathrm{B}-300 \mu \mathrm{M} ; \mathrm{C}-1 \mu \mathrm{M} ; \mathrm{D}-1 \mu \mathrm{M} ; \mathrm{E}-2 \mu \mathrm{M} ; \mathrm{F}-1 \mu \mathrm{M} ; \mathrm{G}-0,5 \mu \mathrm{M} ; \mathrm{H}-0,5 \mu \mathrm{M}$
} 


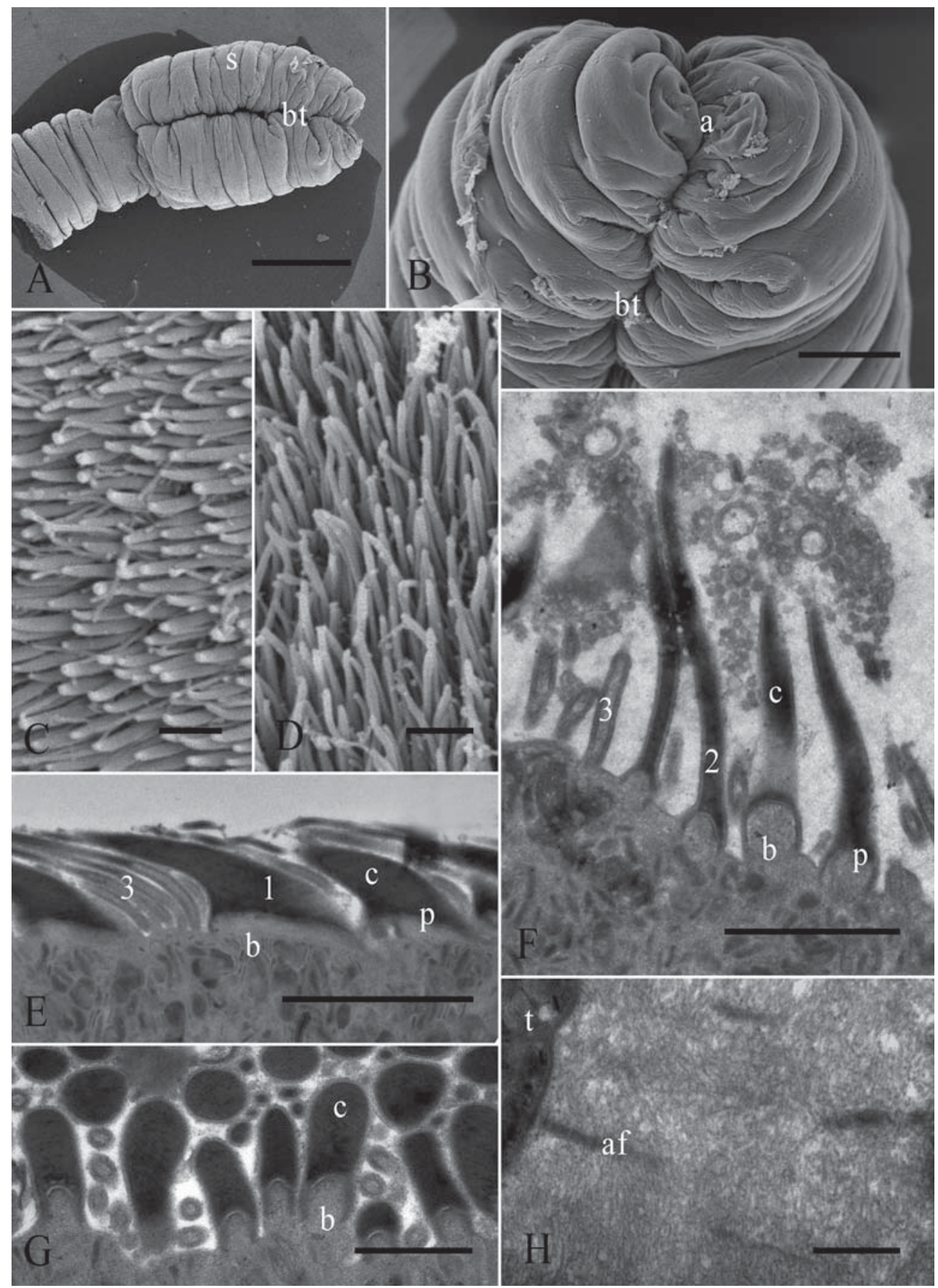

Fig. 1. Pyramicocephalus phocarum: tegument ultrastructure. A, B - scaning electron microscopy images of the scolex with bothrial folds; C - microthriches (type 1) on the bothrial fold; D - microthriches (type 2) on the body; E - microthriches (type 1 and 3, sagital section); F - slim conical microthriches (type 2; sagital section); $\mathrm{G}$ - microthriches (type 1; frontal section); $\mathrm{H}$ - ultrastructure of the basal lamina with the anchoring fibrils. 


\section{Results and discussion}

The ultrastructure of the plerocercoid's tegument of the scolex and body has been studied using scanning and transmission electron microscopy. The semitriangular scolex has dorsal and ventral bothria with distinctly undulating margins (Fig. 1A, B). Three types of microthriches are found on the tegument surface. Each type has a different shape and ultrastucture. 1. Spinithrix microthriches (according to the classification of Chervy, 2009) have a rounded apical cap with retroversion (Fig. 1C) on the scanning electron microscope view. In ultrathin sections, spinithrix microthriches have a flatconical shaped electron dense apical cap and a massive wide base (Fig. 1E). The base is $1.6 \mu \mathrm{m}$ in diameter and $0.3 \mu \mathrm{m}$ in height. The cytoplasmic core of the base contains light cytoplasm; an electron-dense tunic is asymmetrical and is more developed on the anterior side of the base. These microthriches are distributed predominantly in the tegument of the bothrial folds. 2 . Slim conical microthriches with a pointed apical cap (length of the apical part $-2.2 \mu \mathrm{m}$ ) are distributed across the body surface. The diameter of the base is $0.3 \mu \mathrm{m}$, cytoplasmic core is reinforced by an electron-dense tunic. (Fig. 1D, F). 3. Cylindrical fillithriches have a long base $(1.1 \mu \mathrm{m})$ and short apical cap. They are distributed on the scolex and body surface (Fig. 1E).

It was confirmed for Cestoda that the morphology and distribution of microthriches is consistent at various taxonomic levels (Chervy L., 2009). The distribution of microthriches on the scolex and body surface of $P$. phocarum has specific features and correlates with functional specialization. The $1^{\text {st }}$ and the $2^{\text {nd }}$ types have a reinforced base and, therefore, they have fixa- tive-mechanical specializations. The wide base of mitrotriches and their incline towards the back of the body prevents the ejection of the parasite and counteracts the reverse movement of the tapeworms. These mitrotriches also function similar to a "hook and loop fastener", attaching the cestode's tegument to the host's intestine. The $3^{\text {rd }}$ type - cylindrical fillithriches - are specializied for membrane digestion, similar to the intestine microvilli (Ugolev, 1972). The membrane digestion surface is increased by several times by membranes of the fillithrix base (Biserova, 1987, 1991). In Diphyllobothrium latum (L). plerocercoids, claviform microthriches have been found in the scolex tegument (Kuperman, 1988). We have found similarly shaped microtriches on cross sections on the bothrial folds in P. phocarum (Fig. 1G). We suppose that the claviform shape is a result of a frontal section through type 1 spinithrix microtriches.

The tegumental syncytium of $P$. phocarum is composed of an anucleate distal cytoplasm and perinuclear cell bodies, which lie deep in the tegument (tegumental cytons). The distal cytoplasm contains electron-dense bodies, electron-lucent vesicles, and mitochondria, which are associated with the basal membrane. The basal lamina consists of an electron-dense homogeneous layer of lamina dense (up to $40 \mathrm{~nm}$ in thickness), and a fibrillar layer, lamina reticularis (varied in thickness from 0.5 to $3.4 \mu \mathrm{m}$ ). The basal lamina is adjacent to the tegument and the muscles cells associated with it. Circular and longitudinal muscles are localized beneath the basal lamina. We found thin densities within the lamina reticularis that are oriented orthogonally (or radially in respect to the longitudinal axis) to the basal tegumental membrane (Fig. 1H).

\footnotetext{
Abbreviations: $\mathrm{g}$ - granules; $\mathrm{l}$ — lateral process; $\mathrm{m}$ - microtubules; $\mathrm{n}$ - nucleus; $\mathrm{r}$ - ribosome; $\mathrm{rt}$ - root; sd septate desmosome; $\mathrm{sr}$ - supporting ring; $\mathrm{t}$ - tegument. Scale bar: A $-2 \mu \mathrm{m}$; B $-1 \mu \mathrm{m} ; \mathrm{C}-1 \mu \mathrm{m} ; \mathrm{D}-1 \mu \mathrm{m}$. Рис. 2. Строение фронтальных желез и рецептора. A - перикарион с ядром и секреторными гранулами в цитоплазме; В - проток в тегументе; C - резервуар с секреторными гранулами и периферическими микротрубочками; D - механо-тактильный рецептор (6 тип) с коническим исчерченным корешком и 2 опорными кольцами под септированной десмосомой.

Сокращения: $\mathrm{g}$ — гранулы секрета; $\mathrm{lp}$ — боковой отросток; $\mathrm{m}$ - микротрубочки; $\mathrm{n}$ — ядро; $\mathrm{r}$ - рибосома; $\mathrm{rt}$ корешок; sd - септированная десмосома; sr - опорное кольцо; $\mathrm{t}$ - тегумент. Масштаб: А $-2 \mu \mathrm{M} ; \mathrm{B}-1 \mu \mathrm{M}$; $\mathrm{C}-1 \mu \mathrm{M} ; \mathrm{D}-1 \mu \mathrm{M}$.
} 

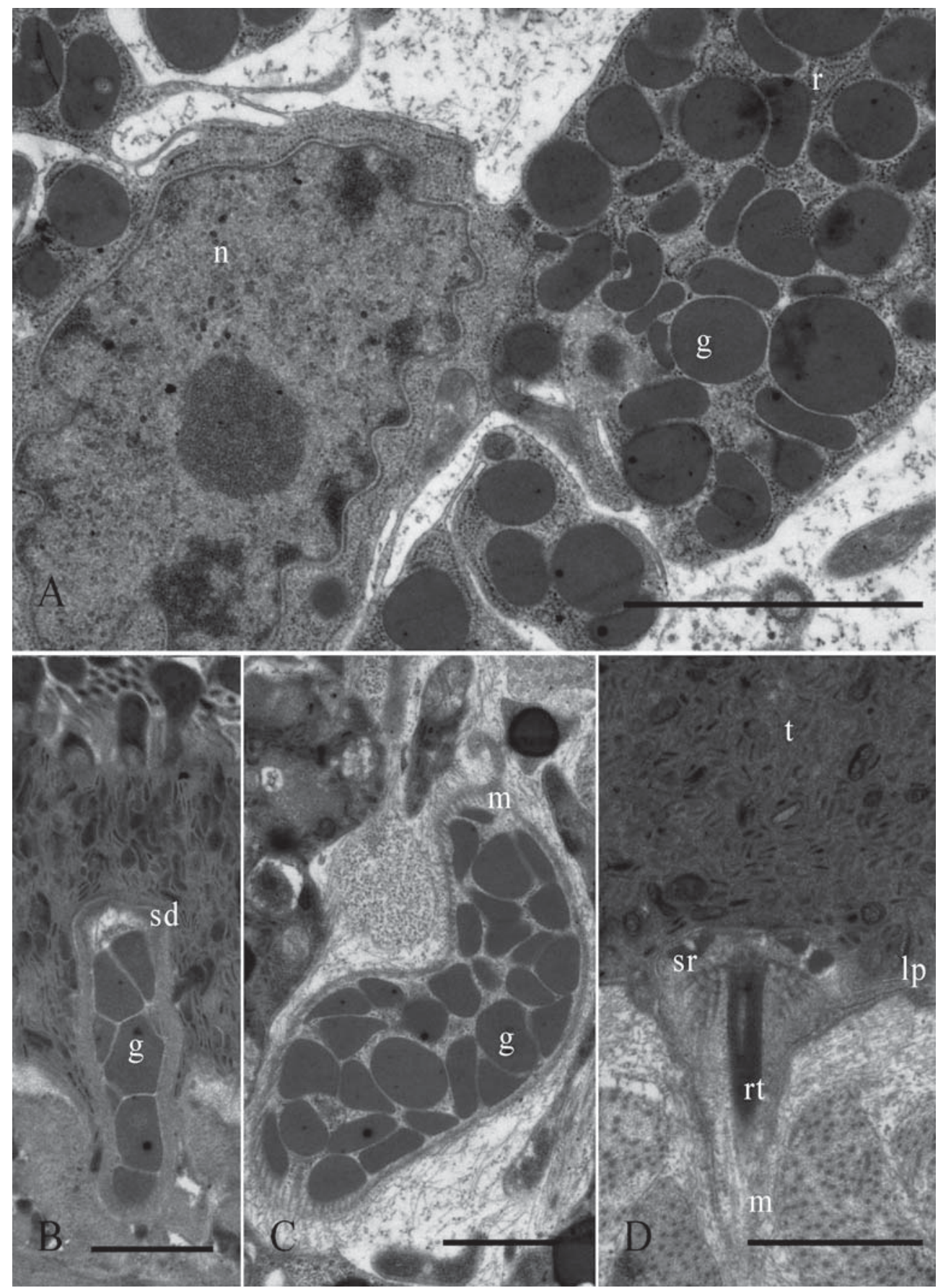

Fig. 2. Ultrastructure of the frontal glands and sensory nerve ending ( $6^{\text {th }}$ type). A - perikaryon with nucleus and secretory granules in the cytoplasm located in the central parenhyma; B - terminal duct in the tegument; $\mathrm{C}$ - the reservoir with secretory granules reinforced by peripheral microtubules; D - mechano-tactile free nerve ending in the bothrial tegument (type 6) with conical striated root and 2 supporting rings. 
According to Holy and Oaks (1987), these radial densities are the anchoring fibrils. In $P$. phocarum, these radial anchoring fibrils are associated with the microfibrills of the lamina reticularis and form cross-links. The apical end of these anchoring fibrils is connected to the lamina dense and the other end is directly linked to the subtegumental muscle fibers. They form electron-dense hemi-desmosomes at both ends.

Well-developed frontal glands were found in the scolex and body of the $P$. phocarum plerocercoid. Frontal glands form a multinuclear secretory apparatus with many perikarya, reservoirs with secretory granules, and secretory ducts, which extend to the bothrial margines and the apex. Perikarya have large nuclei and rich GER in the cytoplasm and also oval electron-dense secretory granules $850 \mathrm{~nm}$ in size (Fig. 2A). In the peripheral parts of the glandular syncytium, secretory ducts are reinforced by a system of longitudinally oriented microtubules (Fig. 2C). Reservoirs with great numbers of secretory granules are located in the medullar and cortical layers of parenchyma. The glandular syncytium gives rise to ducts that penetrate the distal tegument. These terminal parts of secretory ducts possess pores in the distal cytoplasm. Like in Diphyllobothrium ditremum (Creplin, 1825) (Biserova, Kemaeva, 2012), in $P$. phocarum the pores are surrounded with specialized contacts such as circular septate desmosomes and one electron-dense supporting ring (Fig. 2B). The ducts discharge their secretion into the host by an eccrine secretion mechanism, the same as in other plerocercoids (Kuperman, 1988; Moreno et al., 2001). The glandular complex fills the scolex parenchyma from the anterior to the posterior end and continued into the body. In comparison with other diphyllobothridean plerocercoids, the structure and development of the frontal glands in plerocercoid $P$. phocarum is close to D. latum (Kuperman, Davydov, 1981). In the apical part of the bothria fold we found 30 secretory ducts penetrating the tegument and excreting secretory material into the host. Apical pores of the secretory ducts are usually associated with free sensory endings (Davydov, Biserova, 1985). In
P. phocarum we calculated 50 receptors in the same section of the bothria fold in which 30 secretory ducts have been found. Six types of sensory organs were detected in the tegument of the bothrial fold (Fig. 2D, 3A-F). A similar "sensory-glandular" complex has been found in plerocercoids of $D$. ditremum (Biserova, Kemaeva, 2012), Diphyllobothrium dendriticum (Nitzsch, 1824) (Kutyrev et al., 2017) and Grillotia erinaceus (Beneden, 1858) (Davydov, Biserova, 1985). Also, it is significant that frontal glands function under the control of the central nervous system, which was shown for $D$. ditremum, G. erinaceus and Echinobothrium typus (Beneden, 1849). In the D. ditremum, neurons of the median brain commissure possess electrical synapses with glandular cells membranes (Biserova, Kemaeva, 2012). Terminal part of the ducts of $D$. dendriticum has

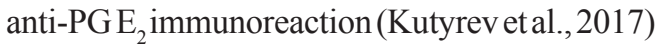
and demonstrates strong impact on the hostparasites interactions, which is implemented by the frontal glands of diphyllobothriidean plerocercoids. Our ultrastructural investigation of the $P$. phocarum plerocercoids detected a number of similar features with the Diphyllobothri$u m$ species and particularly with $D$. latum plerocercoids. Comparative ultrastructural analysis of 4 diphyllobothriidean species showed similarity in the ultrastructure of microtriches and frontal glands of $P$. phocarum and D. latum.

\section{Acknowledgements.}

This work was supported by the Russian Foundation for Basic Research (\# 15-04-02645) and by the International Union of Biological Sciences (IUBS Conference Grant and IUBS Young Scientists Grant). We are grateful to Prof Alexander B. Tsetlin and the employees of the WSBS MSU and Laboratory of Electron Microscopy, Faculty of Biology, MSU, for technical support.

\section{References}

Biserova N.M. 1987. [Structure of integument in plerocercoids and mature Grillotia erinaceus (Cestoda, Trypanorhyncha)] // Parazitologia. Vol.21. No.1. P.2634 [in Russian, with English summary]. 

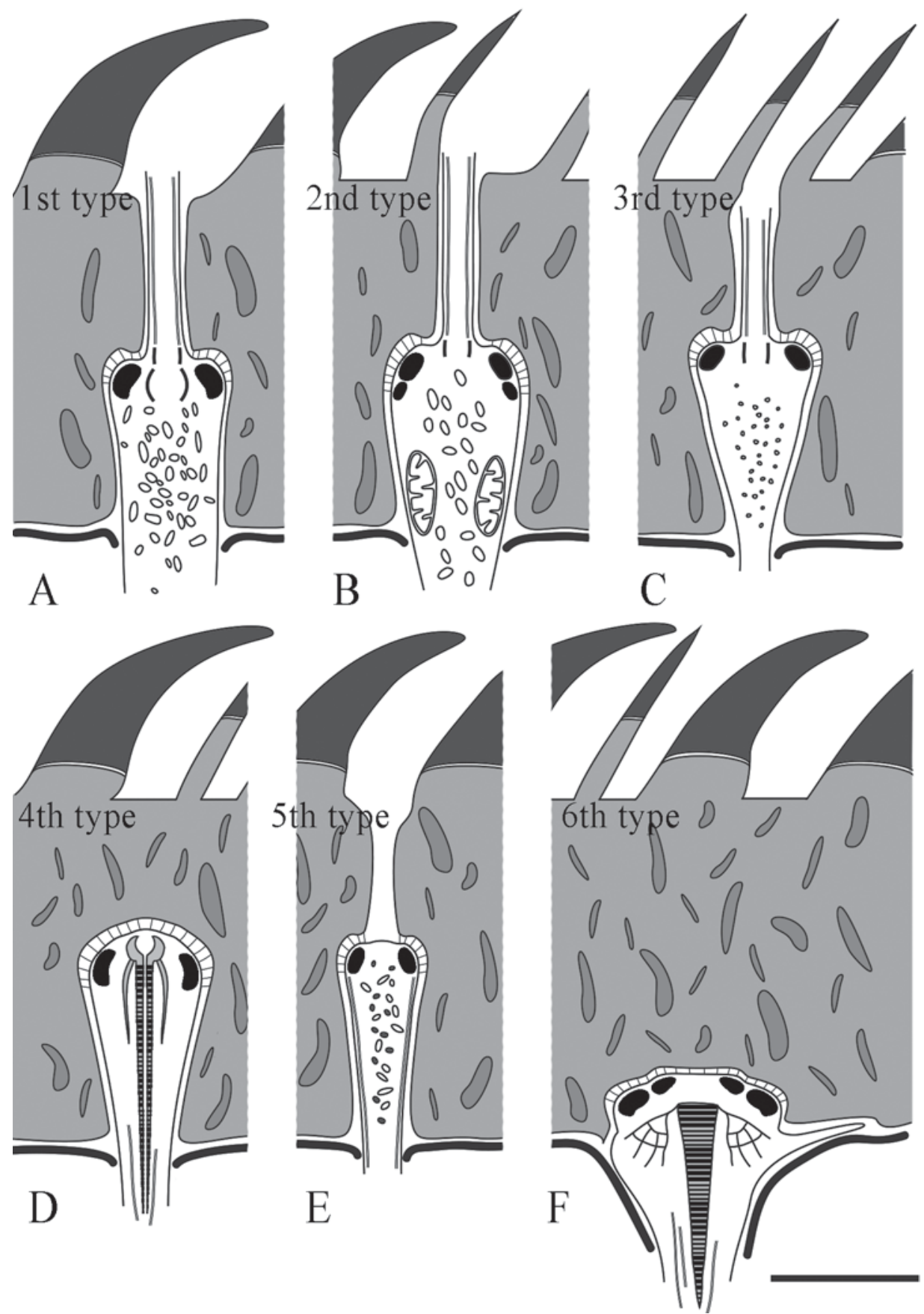

Fig. 3. Schematic drawing of the free nerve endings in the bothrial tegument. A, B, C - ciliated receptors; D, E, F - unciliated receptors. Scale bar $1 \mu \mathrm{m}$.

Рис. 3. Схема тонкого строения свободных нервных окончаний в тегументе ботрии. А, B, C ресничные рецепторы; D, E, F - безресничные рецепторы. Масштаб 1 мм. 
Biserova N.M. 1991. [Ultrastructure of scolex and the tegument of the strobila in Echinobothrium typus (Cestoda: Diphyllidea)] // Tr. Zool. Inst. Acad. Sci. USSR. Vol.241. P.153-172 [in Russian, with English summary].

Biserova N.M. 2013. [Methods of visualization for biological ultrastructures]. KMK Scientific Press Ltd., Moscow. 104 p. [in Russian]

Biserova N.M., Kemaeva A.A. 2012. [The innervations of the frontal gland in scolex of the plerocercoid Diphyllobothrium ditremum (Cestoda: Diphyllobothriidea)] // Problems in Cestodology. Vol.4. P.13-33 [in Russian, with English summary].

Chervy L. 2009. Unified terminology for cestode microtriches: a proposal from the International Workshops on Cestode Systematics in 2002-2008 // Folia Parasitologica. Vol.56. No.3. P.199.

Davydov V.G., Biserova N.M. 1985. The morphology of two types of frontal glands of Grillotia erinaceus (Cestoda: Trypanorhyncha) // Parazitologia. Vol.19. No.1. P.32-38 [in Russian, with English summary].

Holy J.M., Oaks J.A. 1987. Mechanical integration of muscle, tegument, and subtegumental tissues by anchoring fibrils and microfibrils in the cestode Hymenolepis diminuta // Tissue and cell. Vol.19. No.6. P.881-891.

Kuchta R., Scholz T., Brabec J., Bray R.A. 2008. Suppression of the tapeworm order Pseudophyllidea (Platyhelminthes: Eucestoda) and the proposal of two new orders, Bothriocephalidea and Diphyllobothriidea // International journal for parasitology. Vol.38. No.1. P.49-55.

Kutyrev I.A., Biserova N.M., Olennikov D.N., Korneva J.V., Mazur O.E. 2017. Prostaglandins E 2 and D $2-$ regulators of host immunity in the model parasite Diphyllobothrium dendriticum: An immunocytochemical and biochemical study // Molecular and Biochemical Parasitology. Vol.212. P.33-45.

Kuperman B.I. 1988. [Functional Morphology of Lower Cestodes: Ontogenetic and Evolutionary Aspects]. Leningrad: Nauka. 167 p. [in Russian, with English summary]

Kuperman B.I., Davydov V.G. 1981. The fine structure of glands in oncospheres, procercoids and plerocercoids of Pseudophyllidea (Cestoidea) // International journal for parasitology. Vol.12. No.2-3. P.135-144.

Moreno M.J., Casado N., Urrea-París M.A., RodriguezCaabeiro F. 2001. Evidence of tubulin in the scolex gland ducts of Gymnorhynchus gigas plerocercoid (Cestoda: Trypanorhyncha) // Folia parasitologica. Vol.48. No.2. P.163-164.

Rausch R.L., Scott E.M., Rausch V.R. 1967. Helminths in Eskimos in western Alaska, with particular reference to Diphyllobothrium infection and anemia // Transactions of the Royal Society of Tropical Medicine and Hygiene. Vol.61. No.3. P.351-357.

Rausch R.L., Adams A.M., Margolis L. 2010. Identity of Diphyllobothrium spp. (Cestoda: Diphyllobothriidae) from sea lions and people along the Pacific coast of South America // J. Parasitol. Vol.96. No.2. P.359365.

Delyamure S.L. 1955. [Helminthofauna of marine mammals of the world in light of their ecology and phylogeny]. Moscow: AN SSSR Publ. 518 p. [in Russian, with English Ed. Israel Program for Scientific Translations, Jerusalem, 1968]

Ugolev A.M. 1972. Membrane digestion // Gut. Vol.13. No.9. P.735-747.

Responsible editor E.N. Temereva 